\title{
Induction of DNA Damage in L5178Y Cells Treated with Gold Nanoparticle
}

\author{
Jin Seok KAnG ${ }^{1}$, Young Na Yum², Joo Hwan $\mathrm{KIm}^{2}$, Hyuna Song ${ }^{2}$, Jinyoung Jeong ${ }^{3}$, Yong Taik $\mathrm{LIm}^{3}$, \\ Bong Hyun $\mathrm{CHUNG}^{3}$, and Sue Nie PARK ${ }^{2, *}$ \\ ${ }^{1}$ Department of Biomedical Laboratory Science, Namseoul University, Cheonan 330-707, ${ }^{2}$ Department of Toxicological Researches, \\ National Institute of Toxicological Research, Korea Food and Drug Administration, Seoul 122-704, ${ }^{3}$ Bionanotechnology Research Center, \\ Korea Research Institute of Bioscience and Biotechnology, and Nanobiotechnology Major, Korea University of Science \\ and Technology, Daejeon 305-806, Republic of Korea
}

(Received December 10, 2008; Revised December 29, 2008; Accepted January 7, 2009)

\begin{abstract}
As nanomaterials might enter into cells and have high reactivity with intracellular structures, it is necessary to assay possible genotoxic risk of them. One of these approaches, we investigated possible genotoxic potential of gold nanoparticle (AuNP) using L5178Y cells. Four different sizes of AuNP $(4,15,100$ or $200 \mathrm{~nm}$ ) were synthesized and the sizes and structures of AuNP were analyzed using transmission electron microscopy (TEM), scanning electron microscopy (SEM) and stability was analyzed by a UV/Vis. Spectrophotometer. Cytotoxicity was assessed by direct cell counting, and cellular location was detected by dark field microscope at 6,24 and $48 \mathrm{~h}$ after treatment of AuNP. Comet assay was conducted to examine DNA damage and tumor necrosis factor (TNF)- $\alpha$ mRNA level was assay by real-time reverse transcription polymerase chain reaction. Synthetic AuNP (4, 50, 100 and $200 \mathrm{~nm}$ size) had constant characteristics and stability confirmed by TEM, SEM and spectrophotometer for 10 days, respectively. Dark field microscope revealed the location of AuNP in the cytoplasm at 6, 24 and $48 \mathrm{~h}$. Treatment of $4 \mathrm{~nm}$ AuNP induced dose and time dependent cytotoxicity, while other sizes of AuNP did not. However, Comet assay represented that treatment of $100 \mathrm{~nm}$ and $200 \mathrm{~nm}$ AuNP significantly increased DNA damage compared to vehicle control ( $p$ $<0.01$ ). Treatment of $100 \mathrm{~nm}$ and $200 \mathrm{~nm}$ AuNP significantly increased TNF- $\alpha$ mRNA expression compared to vehicle control ( $p<0.05, p<0.01$, respectively). Taken together, AuNP induced DNA damage in L5178Y cell, associated with induction of oxidative stress.
\end{abstract}

Keywords: Genetic toxicity, Gold nanoparticle, L5178Y cell, DNA damage

\section{INTRODUCTION}

Natural occurring nanomaterials include bacteria, virus, ultrafine dust and synthetic materials include metal-based ones, carbon-based ones, dendrimers and so on. Nanomaterials can be applied to bioimaging, cell isolation, therapeutics and diagnostics by using nanobiotechnology. Due to their size, nanomaterials often exhibit unique physical/chemical properties and they are often much more reactive due to their larger surface area (Thomas and Sayre, 2005; Nel et al., 2006). Using these characteristics, many scientists have big interest and enthusiasm in many fields using nanomaterials.

While nanotechnology seems to have commercial

${ }^{*}$ Corresponding author

Tel: +82-2-380-1792 Fax: +82-2-388-6453

E-mail: suenie@kfda.go.kr promise and potential benefit, an equally large issue is the evaluation of potential effects on human and environmental health (Holsapple and Lehman-McKeeman, 2005). It is urgently required and achievable to ensure safe manufacture and use of nanomaterials in the marketplace (Nel et al., 2006). International efforts to develop risk-based safety evaluations for nanomaterials have been started for safety evaluations (Thomas et al., 2006a). Furthermore, there is very little information available regarding associated risks from these exposures (Thomas et al., 2006b).

And it seems that the development of improved strategies for assessing risk and improving public health are needed (Balshaw et al., 2005), and it should be set safety evaluation for nanomaterials to develop nanotechnology (Maynard et al., 2006).

It has been reported that nanomaterials might facilitates their uptake into cells and transcytosis across epithelial 
and endothelial cells into body and lymph circulation to reach potentially sensitive target organs (Oberdorster et al., 2005) and they have increased reactivity in cells (Thomas and Sayre, 2005). And even more, recent reports suggest that they can bind to DNA or amino acid (Nel et al., 2006) and carbon nanotubes were seen to enter the cytoplasm and localize within the cell nucleus, causing cell mortality in a dose-dependent manner (Porter et al., 2007). From these results, it is possible that nanomaterials may induce genotoxicity in certain circumstances.

Actually, it has been reported that some nanomaterials could induce genotoxicity in some situations. For example, it was reported that fullerenes induced DNA damage, possibly associated with oxidative stress (Dhawan et al., 2006), and genotoxicity of zinc oxide was enhanced in irradiated circumstance (Dufour et al., 2006). And ultrafine titanium dioxide induced micronuclei and apoptosis in vitro (Rahman et al., 2002), and it can induce oxidative damage to human bronchial epithelial cells even in the absence of photoactivation (Gurr et al., 2005).

Gold nanoparticle has been developed as an agent for cell imaging, drug delivery and cancer diagnostics (ElSayed et al., 2005). Recent study reported that gold nanoparticles entered the cells via endocytosis pathway (Chithrani et al., 2006) and they exocytosed out of the cells in a linear relationship to size (Chithrani and Chan, 2007). These studies made us investigate the possible genotoxicity of gold nanoparticles. We tested synthesized gold nanoparticle (AuNP) at four different sizes and at three treatment doses, and investigated cellular toxicity, cellular location, DNA damage and oxidative stress-related genes.

\section{MATERIALS AND METHODS}

\section{Materials}

Dulbecco's modified Eagle's medium (DMEM), fetal bovine serum (FBS) and penicillin-streptomycin were purchased from Invitrogen (Carlsbad, CA). Methyl methanesulphonate (MMS) was obtained from Sigma (St. Louis, MO).

\section{Cell line and cell culture}

L5178Y was purchased from American Type Culture Collection (ATCC, Manassas, VA), and was cultured in DMEM medium supplemented with $1.5 \mathrm{~g} / \mathrm{L}$ sodium bicarbonate, $10 \% \mathrm{FBS}$ and $1 \%$ penicillin at $37^{\circ} \mathrm{C}$ in a $5 \% \mathrm{CO}_{2}$ atmosphere.

\section{Synthesis and chemical characteristics of AuNP}

Four different sizes of AuNP $(4,15,100$ or $200 \mathrm{~nm})$ were used in this work. The $4 \mathrm{~nm}$ gold nanoparticles were prepared by the method of Jana et al. (Jana et al., 2001) following as: two hundred milliliter of aqueous solution containing $0.25 \mathrm{mM} \mathrm{HAuCl}_{4}$ and $0.25 \mathrm{mM}$ citric acid was prepared in conical flask. Then $6 \mathrm{ml}$ of $0.1 \mathrm{M}$ sodium borohydride $\left(\mathrm{NaBH}_{4}\right)$ were added to the solution with stirring at room temperature. The solution color immediately turned to pink, and the solution kept stirring for $10 \mathrm{~min}$. The $15 \mathrm{~nm}$ gold nanoparticles were synthesized by following Fren's method (Frens, 1973). In brief, $250 \mathrm{ml}$ of $1 \mathrm{mM} \mathrm{HAuCl}_{4}$ dissolved in water was heated with stirring, and $50 \mathrm{ml}$ of $1 \%$ citric acid was added and further heated for $15 \mathrm{~min}$, then cooled at room temperature. The $100 \mathrm{~nm}$ and $200 \mathrm{~nm}$ AuNPs were used as-received from BBInternational Co. (UK). All AuNPs were protected by thiol-terminated poly (ethylene)glycol (HS-PEG, MW. 5,000 for 4, $15 \mathrm{~nm}$ or MW. 30,000 for $100,200 \mathrm{~nm}$ ). Aqueous solution of $0.1 \% \mathrm{HS}$ PEG was added into AuNP solution and kept stirring for 4 h. Finally, the AuNP solutions were exchanged with PBS buffer by dialysis $(4 \mathrm{~nm})$ or centrifugation $(15,100,200$ $\mathrm{nm})$.

The size and structure of PEG-coated AuNPs were analyzed using a field-emission scanning electron microscopy (FE-SEM, FEl, USA) at an accelerating voltage of $10 \mathrm{kV}$. The transmission electron microscopy images were obtained using a CM20 (Philips, Eindhoven, Netherlands) at an acceleration voltage of $120 \mathrm{kV}$. The UV/Vis absorption spectra were recorded on a UV/Vis. Spectrophotometer (DU-800, Beckman Coulter, USA).

\section{Cytotoxicity assay}

Cytotoxicity was assessed by direct cell counting. In brief, L5178Y cells $\left(2 \times 10^{5}\right.$ cells $\left./ \mathrm{ml}\right)$ were treated with four sizes of AuNP (4, 15, 100 and $200 \mathrm{~nm})$ and were incubated for 6,24 or $48 \mathrm{~h}$ at the concentration of $0,6.25,12.5,25$, 50,100 and $200 \mu \mathrm{g} / \mathrm{ml}$, and cell counting was carried out.

\section{Cellular location}

L5178Y cells $\left(2 \times 10^{5}\right.$ cells $\left./ \mathrm{ml}\right)$ were treated with four different sizes of AuNP and the cells were fixed with $4 \%$ paraformaldehyde in $0.1 \mathrm{M}$ PBS buffer. Cellular location was detected by dark field microscope (Nikon, Japan) at 6, 24 and $48 \mathrm{~h}$ after treatment of AuNP.

\section{Comet assay}

Cells $\left(1 \times 10^{5}\right.$ cells $\left./ \mathrm{ml}\right)$ were cultured in 12-well plate were treated with four different sizes of $\operatorname{AuNP}(4,15,100$ or $200 \mathrm{~nm})$ as low dose $(25 \mu \mathrm{g} / \mathrm{ml})$, middle dose $(50 \mu \mathrm{g} / \mathrm{ml})$ and high dose $(100 \mu \mathrm{g} / \mathrm{ml})$ for $2 \mathrm{~h}$. Cells were mixed with LMAgarose, and these mixture was put into Comet Slide ${ }^{\mathrm{TM}}$ 
(Trevigen, MD) and then into lysis solution for 30-60 min at $4^{\circ} \mathrm{C}$, alkaline solution for 30-60 min, and were carried out electrophoresis for $30 \mathrm{~min}$, and were dried out after dipping into $70 \%$ alcohol. And then these were stained with ethidium bromide and examined by fluorescene microscope, and were analyzed by Comet assay program (Komet 3.1, Andor Technology, Belfast, UK) to calculate tail moment. MMS (325.75 mg/ml) was used as positive control.

\section{Tumor necrosis factor (TNF)- $\alpha$ mRNA expression by real-time reverse transcription polymerase chain reaction (RT-PCR)}

Total RNAs were extracted for gene expression analysis using the RNeasy Mini kit (Qiagene, Valencia, CA). The yield of RNA was determined by Bioanalyzer 2100 (Agilent Technology, CA), and stored at $-80^{\circ} \mathrm{C}$ until use.

For cDNA synthesis $\operatorname{TaqMan}^{\circledR}$ Gold RT-PCR Kit (Applied Biosystmes, CA) was used according to manufacturer's guide. In brief, $2 \mu \mathrm{g}$ of total RNA was mixed with $10 \mu \mathrm{l}$ of 10X RT Buffer, $22 \mu \mathrm{l}$ of $25 \mathrm{mM} \mathrm{MgCl}_{2}, 20 \mu \mathrm{l}$ of deoxyNTPs mixture, $5 \mu$ of random hexamers, $2 \mu \mathrm{l}$ of RNase inhibitor, $2.5 \mu$ of MultiScribe Reverse Transcriptase $(50 \mathrm{U} / \mu \mathrm{l})$ and incubate at $25^{\circ} \mathrm{C}$ for $10 \mathrm{~min}$, at $37^{\circ} \mathrm{C}$ for $1 \mathrm{~h}$, and at $95^{\circ} \mathrm{C}$ for $5 \mathrm{~min}$ and placed on ice for $10 \mathrm{~min}$ and stored at $-20^{\circ} \mathrm{C}$ until use.

cDNAs were amplified using oligonucleotide primers and probe (Applied Biosystems, CA) for TNF- $\alpha$ mRNA. PCR amplification was carried out according to the manufacturer's instruction (Applied Biosystems, CA). The PCR program cycles were set as follows: initial denaturing at $50^{\circ} \mathrm{C}$ for $20 \mathrm{~min}, 95^{\circ} \mathrm{C}$ for $10 \mathrm{~min}$, followed by 40 cycles $\left(95^{\circ} \mathrm{C}\right.$ for $15 \mathrm{~s}, 60^{\circ} \mathrm{C}$ for $\left.1 \mathrm{~min}\right)$.

$\beta$-actin mRNA was employed as an internal standard, and each gene expression was determined by real- time RT-PCR and normalized against $\beta$-actin mRNA levels. All PCR products were amplified in a linear cycle. Data are the mean \pm SD from three samples per group of two independent experiments.

\section{Statistical analysis}

Statistical analyses for cytotoxicity, Comet assay and real-time RT-PCR data were performed with the TukeyKramer method using JMP program (SAS Institute, Cary, $\mathrm{NC}$ ). For all comparisons, probability values less than $5 \%$ $(p<0.05)$ were considered to be statistically significant.

\section{RESULTS}

\section{Chemical characteristics of AuNP}

Color of AuNP showed from red to pink depending on size (data not shown). There were no alterations of size and component of AuNP confirmed by TEM (Fig. 1a-d), SEM (Fig. 1e), and spectrophotometer (Fig. 1f).

\section{Cytotoxicity assay}

Treatment of $4 \mathrm{~nm}$ AuNP induced dose and time dependent cytotoxicity (Fig. 2). At $6 \mathrm{~h}$ after treatment of $4 \mathrm{~nm}$ AuNP, there was a significant difference at the concen-
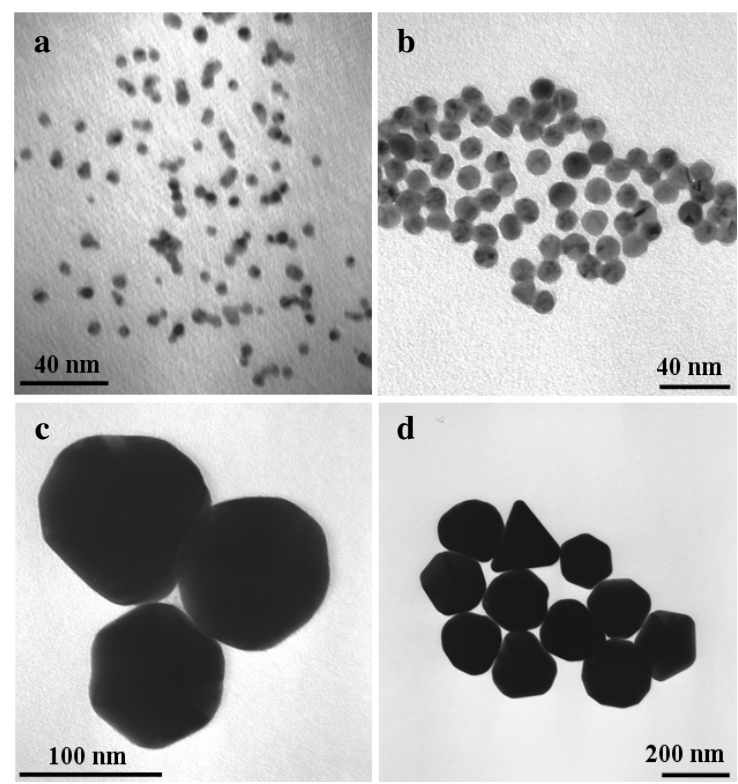

d

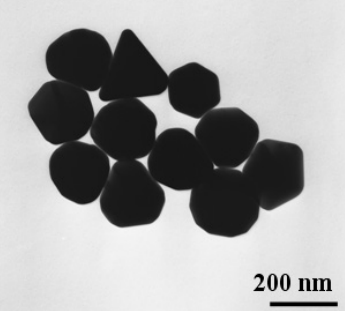

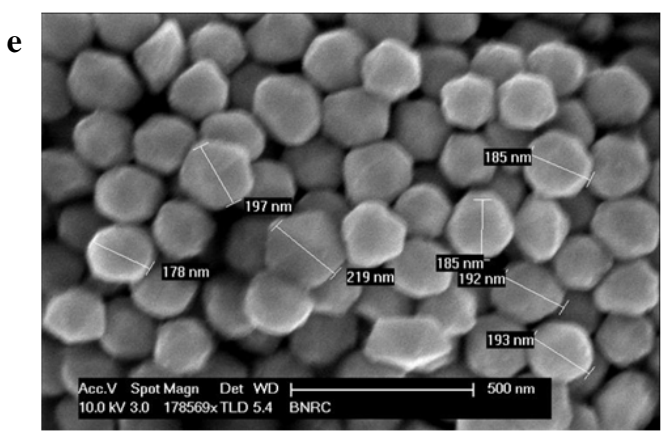

f
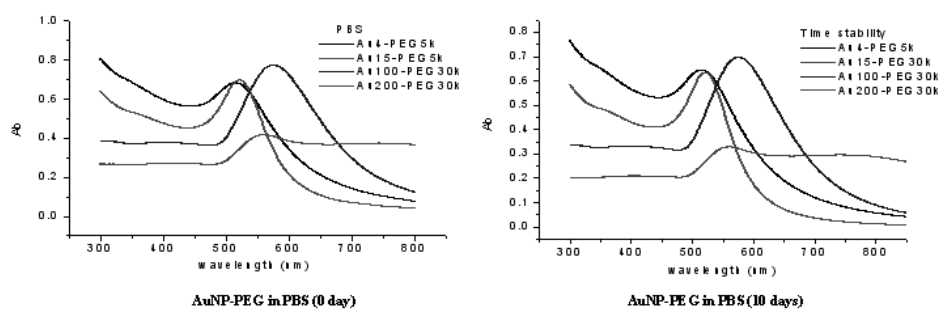

Fig. 1. Characteristics of gold nanoparticle (AuNP). TEM image of 4 (a), 15 (b), 100 (c) and $200 \mathrm{~nm}$ AuNP (d); (e) SEM image of $200 \mathrm{~nm}$ size AuNP; (f) stability of AuNP measured by spectrophotometry. 
tration of $200 \mu \mathrm{g} / \mathrm{ml}$ compared to vehicle control $(p<0.01)$. Moreover, at $24 \mathrm{~h}$ after treatment, there were significant differences at the concentration of 25, 50, 100 and 200 $\mu \mathrm{g} / \mathrm{ml}$ compared to vehicle control ( $p<0.01$, respectively) and at $48 \mathrm{~h}$ after treatment, at the concentration of 50,100 and $200 \mu \mathrm{g} / \mathrm{ml}$ compared to vehicle control $(p<0.05, p$ $<0.01$ or $p<0.01$, respectively). However, 15, 100 and $200 \mathrm{~nm}$ AuNP treatment did not induce cytotoxicity at any dose within $48 \mathrm{~h}$ (data not shown).

\section{Cellular location}

Cells were treated with four different sizes of AuNP (4, 15,100 or $200 \mathrm{~nm}$ ) and the cells were fixed with fixatives, and cellular location was detected by dark field microscope. The nanoparticles were existed in cytoplasm at 6 , 24 and $48 \mathrm{~h}$ after treatment. Representative figure was shown in Fig. 3, illustrating the cellular location of AuNP in cytoplasm, mainly around cell membrane.

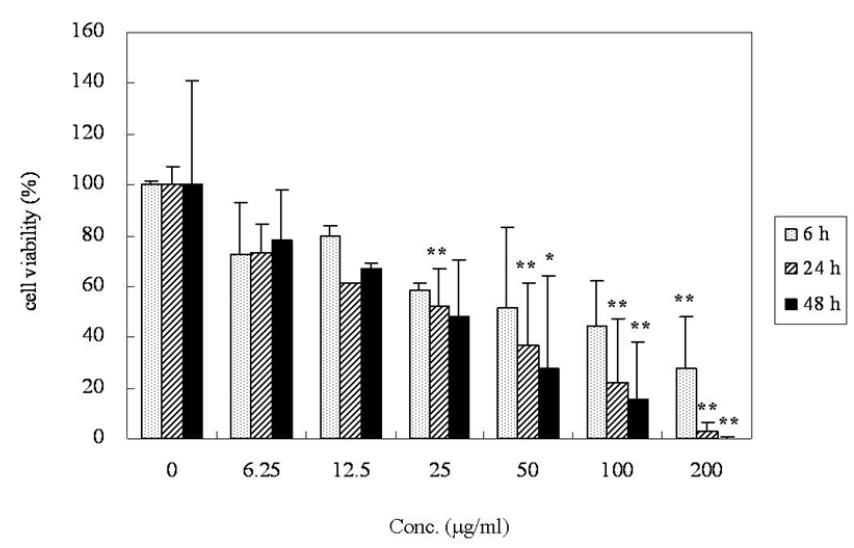

Fig. 2. Cytotoxicity at 4,24 and $48 \mathrm{~h}$ after treatment of $4 \mathrm{~nm}$ AuNP. *, ${ }^{*}$ Significantly different from vehicle control $(p<0.05, p$ $<0.01$, respectively).

\section{Comet assay}

Cell were treated with four different sizes of AuNP $(4,15$, 100 or $200 \mathrm{~nm})$ as low dose $(25 \mu \mathrm{g} / \mathrm{ml})$, middle dose (50 $\mu \mathrm{g} / \mathrm{ml})$ and high dose $(100 \mu \mathrm{g} / \mathrm{ml})$ for $2 \mathrm{~h}$. Treatment of 100 $\mathrm{nm}$ or $200 \mathrm{~nm}$ AuNP significantly increased DNA damage $(p<0.01)$, as equivalent level shown in the treatment of MMS as positive control (Fig. 4). However, treatment of 4 $\mathrm{nm}$ or $15 \mathrm{~nm}$ AuNP did not induce DNA damage.

\section{TNF- $\alpha$ mRNA expression}

Real-time RT-PCR analysis showed that treatment of $100 \mathrm{~nm}$ or $200 \mathrm{~nm}$ AuNP significantly increased TNF- $\alpha$ mRNA expression compared to vehicle control $(p<0.05, p$ $<0.01$, respectively) (Fig. 5). On the while, treatment of 4 $\mathrm{nm}$ or $15 \mathrm{~nm}$ AuNP showed increased values of it.

\section{DISCUSSION}

In the present study, it was showed that treatment of 4 $\mathrm{nm}$ AuNP induced cellular toxicity in L5178Y cells, while 15, 100 or $200 \mathrm{~nm}$ AuNP did not show cytotoxicity. However, DNA damage detected by Comet assay was appeared at the treatment of 100 or $200 \mathrm{~nm}$ AuNP. And the treatment of $15 \mathrm{~nm}$ AuNP did not show cytotoxicity or DNA damage in this study.

It is generally accepted that nanosize materials may be more toxic than micron-sized one, as showing that nanosized cobalt-chromium alloy induced more DNA damage than micron-sized particles (Papageorgiou et al., 2007) and the ultrafine particles elicited a persistently high inflammatory reaction in the lungs of the animals compared to the larger-sized particles (Oberdorster et al., 1994). In concordance with previous reports, the smallest size of AuNP showed cellular toxicity by dose and time-dependent manner in this study.
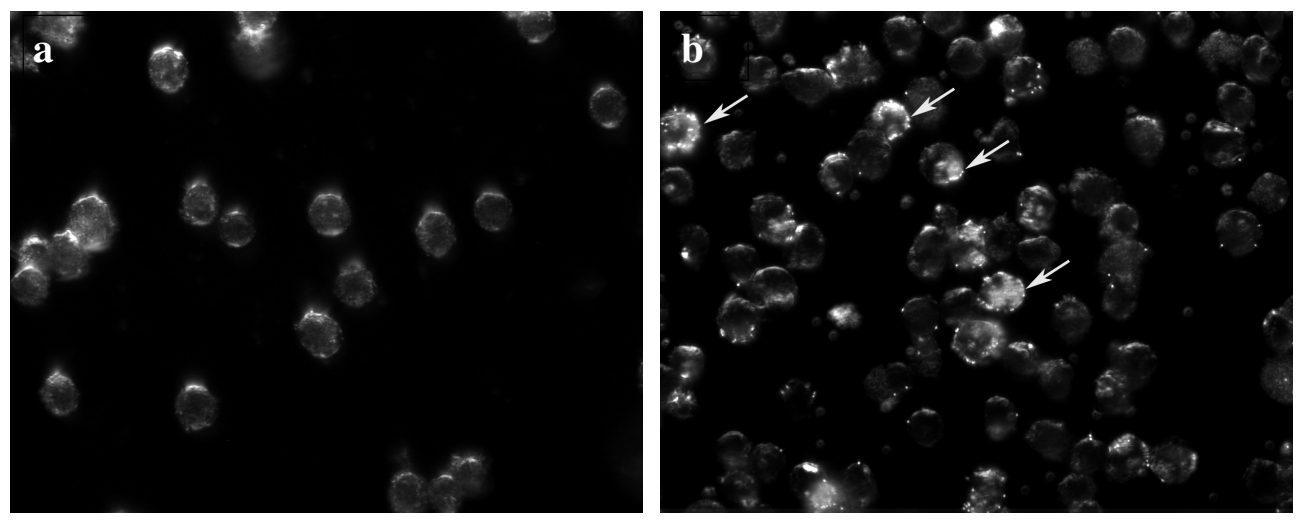

Fig. 3. Cellular location detected by dark field microscope after treatment of AuNP. a) control; b) AuNP $200 \mathrm{~nm}(200 \mu \mathrm{g} / \mathrm{ml})$ at $48 \mathrm{~h}$ after treatment, $\times 800$ magnification; Note the cellular location of AuNP in cytoplasm, mainly around cell membrane (Arrow). 
a

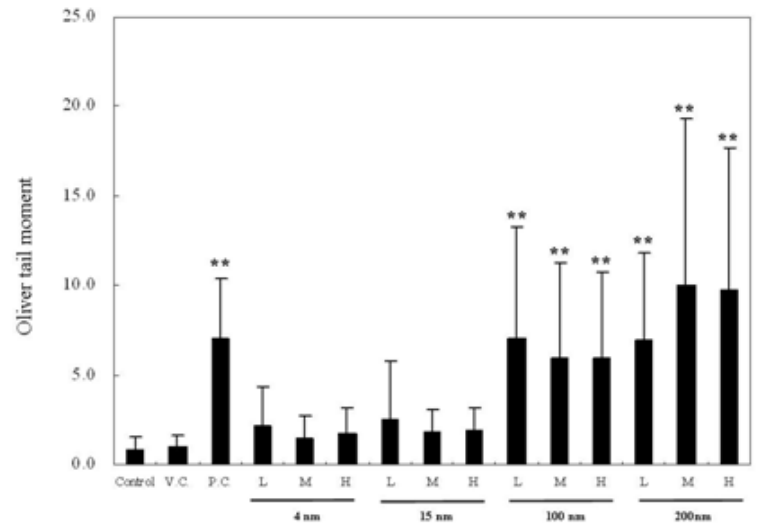

b
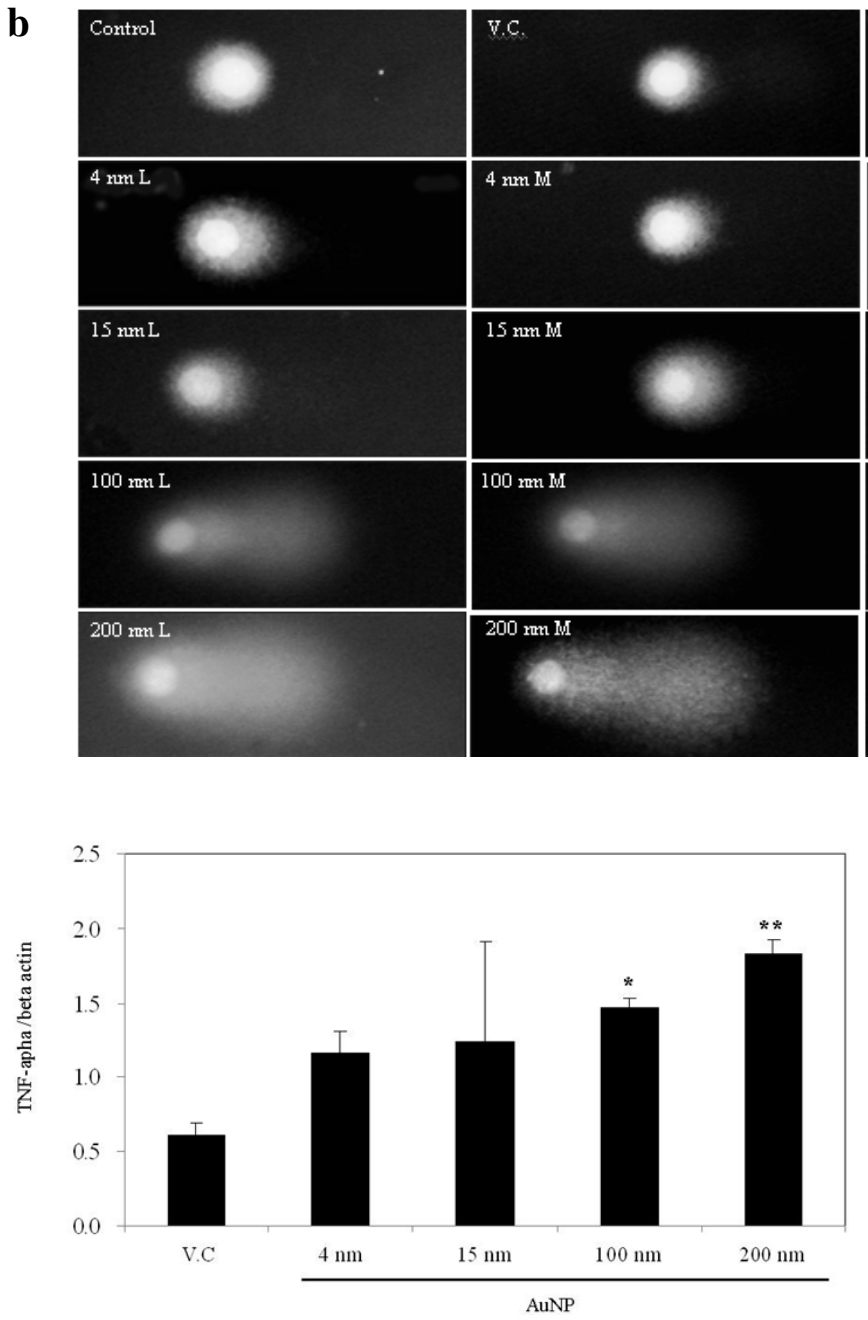

Fig. 5. Real-time RT-PCR analysis of TNF- $\alpha$ mRNA in L5178Y cell treated with AuNP. TNF- $\alpha$ mRNA expression was quantified and normalized with $\beta$-actin mRNA expression as described in the Materials and Methods. Note the significant differences of the gene expression among vehicle control and AuNP treatment $(100$ and $200 \mathrm{~nm}) ;{ }^{*},{ }^{* *}$ Significantly different from vehicle control $(p<0.05, p<0.01$, respectively).

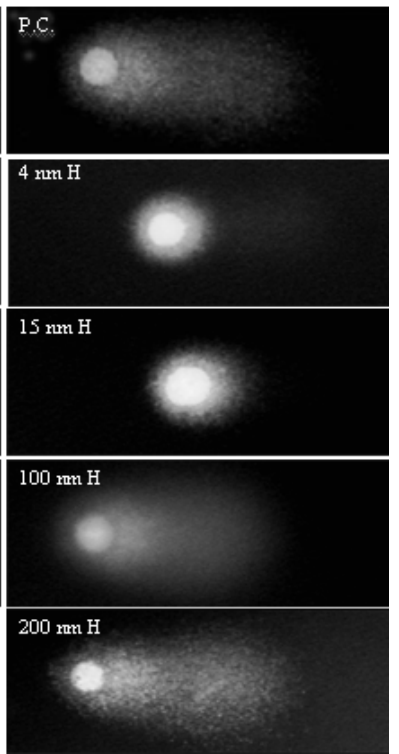

Fig. 4. Comet assay for AuNP. a) DNA damage as represented as oliver tail moment. Note treatment of $100 \mathrm{~nm}$ or $200 \mathrm{~nm}$ AuNP increased DNA damage, as equivalent level shown in the treatment of methyl methanesulphonate (MMS) as positive control; b) Representative figures from control and 4, 15, 100 or $200 \mathrm{~nm}$ AuNP treatment groups; L, $\mathrm{M}$ and $\mathrm{H}$ mean low $(25 \mu \mathrm{g} /$ $\mathrm{ml})$, middle $(50 \mu \mathrm{g} / \mathrm{ml})$ and high dose $(100 \mu \mathrm{g} / \mathrm{ml})$ treatment of four different size of AuNP, respectively; VC: vehicle control; PC: positive control; **Significantly different from vehicle control $(p<0.01)$.

It was reported that uptake of the gold nanoparticles significantly increased for the first $2 \mathrm{~h}$, but the uptake rate gradually slowed and reached a plateau at 4-7 $\mathrm{h}$, depending on size (Chithrani et al., 2006). We examined cellular location of AuNP occurred at 6,24 and $48 \mathrm{~h}$ after treatment. However, we did not clearly determine the quantity by dark-filed microscopy in this study. On the while, we determined DNA damage at $2 \mathrm{~h}$ after treatment of AuNP by Comet assay, which was microgel electorphresis method to find DNA damage directly in cellular level (McNamee et al., 2000). In our study, the treatment of $100 \mathrm{~nm}$ and 200 $\mathrm{nm}$ AuNP significantly increased DNA damage compared to control. So, it seems that AuNP may enter the cell within $2 \mathrm{~h}$ and caused DNA damage only in 100 and $200 \mathrm{~nm}$ AuNP. Interestingly, we found that there were little variation in control and positive control value, in contrast with large variation in the groups of 100 or $200 \mathrm{~nm}$ of AuNP treatment. It seems that there may be different cellular susceptibility and variable level of cellular damage in treated 
cells.

To investigate mechanism of DNA damage, we carried out real-time RT-PCR, representing that AuNP treatment induced TNF- $\alpha$ mRNA. However there was no change of p53 mRNA or Mdm2 mRNA (data not shown). We assume that $4 \mathrm{~nm}$ AuNP might induce cellular toxicity by direct pathway(s), however 100 or $200 \mathrm{~nm}$ AuNP induce DNA damage by indirect mechanism(s), associated with increase of oxidative stress. Further studies will be required to investigate detail mechanism(s) for DNA damage induced by AuNP.

Taken together, AuNP induced DNA damage in L5178Y cell, associated with induction of oxidative stress.

\section{ACKNOWLEDGMENTS}

This research was supported by a research grant (07141KFDA762) from Korea Food and Drug Administration in 2007.

\section{REFERENCES}

Balshaw, D. M., Philbert, M. and Suk, W. A. (2005). Research strategies for safety evaluation of nanomaterials, Part III: nanoscale technologies for assessing risk and improving public health. Toxicol. Sci. 88, 298-306.

Chithrani, B. D. and Chan, W. C. (2007). Elucidating the mechanism of cellular uptake and removal of protein-coated gold nanoparticles of different sizes and shapes. Nano. Lett. 7, $1542-1550$.

Chithrani, B. D., Ghazani, A. A. and Chan, W. C. (2006). Determining the size and shape dependence of gold nanoparticle uptake into mammalian cells. Nano. Lett. 6, 662-668.

Dhawan, A., Taurozzi, J. S., Pandey, A. K., Shan, W., Miller, S. M., Hashsham, S. A. and Tarabara, V. V. (2006). Stable colloidal dispersions of $\mathrm{C} 60$ fullerenes in water: evidence for genotoxicity. Environ. Sci. Technol. 40, 7394-7401.

Dufour, E. K., Kumaravel, T., Nohynek, G. J., Kirkland, D. and Toutain, H. (2006). Clastogenicity, photo-clastogenicity or pseudo-photo-clastogenicity: Genotoxic effects of zinc oxide in the dark, in pre-irradiated or simultaneously irradiated Chinese hamster ovary cells. Mutat. Res. 607, 215-224.

El-Sayed, I. H., Huang, X. and El-Sayed, M. A. (2005). Surface plasmon resonance scattering and absorption of anti-EGFR antibody conjugated gold nanoparticles in cancer diagnostics: applications in oral cancer. Nano. Lett. 5, 829-834.

Frens, G. (1973). Controlled nucleation for the regulation of the particle size in monodisperse gold suspensions. Nature Phys. Sci. 241, 20-22.

Gurr, J. R., Wang, A. S., Chen, C. H. and Jan, K. Y. (2005).
Ultrafine titanium dioxide particles in the absence of photoactivation can induce oxidative damage to human bronchial epithelial cells. Toxicology 213, 66-73.

Holsapple, M. P. and Lehman-McKeeman, L. D. (2005). Forum series: research strategies for safety evaluation of nanomaterials. Toxicol. Sci. 87, 315.

Jana, N.R., Gearheart, L. and Murphy, C.J. (2001). Wet chemical synthesis of high aspect ratio cylindrical gold nanorods. J. Phys. Chem. B. 105, 4065-4067.

Maynard, A. D., Aitken, R. J., Butz, T., Colvin, V., Donaldson, K., Oberdorster, G., Philbert, M. A., Ryan, J., Seaton, A., Stone, V., Tinkle, S. S., Tran, L., Walker, N. J. and Warheit, D. B. (2006). Safe handling of nanotechnology. Nature 444, 267-269.

McNamee, J. P., McLean, J. R., Ferrarotto, C. L. and Bellier, P. V. (2000). Comet assay: rapid processing of multiple samples. Mutat. Res. 466, 63-69.

Nel, A., Xia, T., Madler, L. and Li, N. (2006). Toxic potential of materials at the nanolevel. Science 311, 622-627.

Oberdorster, G., Ferin, J. and Lehnert, B. E. (1994). Correlation between particle size, in vivo particle persistence, and lung injury. Environ. Health Perspect. 102 Suppl 5, 173-179.

Oberdorster, G., Oberdorster, E. and Oberdorster, J. (2005). Nanotoxicology: an emerging discipline evolving from studies of ultrafine particles. Environ. Health Perspect. 113, 823-839.

Papageorgiou, I., Brown, C., Schins, R., Singh, S., Newson, R., Davis, S., Fisher, J., Ingham, E. and Case, C. P. (2007). The effect of nano- and micron-sized particles of cobalt-chromium alloy on human fibroblasts in vitro. Biomaterials $\mathbf{2 8}$ 2946-2958.

Porter, A. E., Gass, M., Muller, K., Skepper, J. N., Midgley, P. A. and Welland, M. (2007). Direct imaging of single-walled carbon nanotubes in cells. Nature Nanotechnology 2, 713717.

Rahman, Q., Lohani, M., Dopp, E., Pemsel, H., Jonas, L., Weiss, D. G. and Schiffmann, D. (2002). Evidence that ultrafine titanium dioxide induces micronuclei and apoptosis in Syrian hamster embryo fibroblasts. Environ. Health Perspect. 110, 797-800.

Thomas, K., Aguar, P., Kawasaki, H., Morris, J., Nakanishi, J. and Savage, N. (2006a). Research strategies for safety evaluation of nanomaterials, part VIII: International efforts to develop risk-based safety evaluations for nanomaterials. Toxicol. Sci. 92, 23-32.

Thomas, K. and Sayre, P. (2005). Research strategies for safety evaluation of nanomaterials, Part I: evaluating the human health implications of exposure to nanoscale materials. Toxicol. Sci. 87, 316-321.

Thomas, T., Thomas, K., Sadrieh, N., Savage, N., Adair, P. and Bronaugh, R. (2006b). Research strategies for safety evaluation of nanomaterials, part VII: evaluating consumer exposure to nanoscale materials. Toxicol. Sci. 91, 14-19. 